\title{
岡山製錬所の硫化鉄鉱の脱銅操業之銅製錬
}

\section{Decopperizing Operation of Pyrite and Refining of Blister Copper at Okayama Smelter}

\author{
正会員四元武四 郎* \\ Takeshirō. YOTSUMOTO
}

\section{1. 緒 言}

同和鉱業岡山製錬所の設立目的は，当社椢原鉣業所で 産出する硫化鉄鉱中に夾雑し，従来末利用資源として廃 棄されていた磁硫鉄鉣を, 鉄資源・硫黄資源として, 経済 的に完全利用するためであつた。当所ではこの未利用資 源の活用のため，小坂製鍊所における経験を生かし，米 国ドル社のフルオソリッド焙焼炉を導入して，鉱石中の 鉄・硫黄の主成分はもちろん少量含有されている銅分も それぞれ脱銅焼鉄鉣・工業用濃硫酸ならびに沈殿銅之し て回収するために，昭和28年 9 月に，焙焼炉(120t/日) 1 基, 接触式硫酸設備(100t/日) 1 基とそれに付帯する 設備の建設を完了して，直ちに操業を開始した。

その後， 2 年を経て，技術面・採算面の両面で明るい 見通しを得て，昭和 31 年 6 月に設備の倍増を完成した。 その後も硫酸需要の増加にともない, 漸次増設を行ない, 現在では脱銅焼鉄鉣 $6,500 \mathrm{t} /$ 月，濃硫酸 $10,000 \mathrm{t} /$ 月，沈 殿銅50t/月を生産しているが，原料鉱石は磁硫鉄鉣の漸 減により硫化鉄鉣が主体となつている。

また一方，硫化鉄鉱の焙焼鉱より銅分を抽出した液か ら沈殿銅として銅回収するのではなく，直接電気銅とし て採取するとともにあわせて輸入銅精鉱ほか沈殿銅等を 電気炉熔錬後電解精製する目的で昭和 35 年 10 月に電気銅 $400 \mathrm{t} /$ 月の生産を開始したが, 現在では輸入粗銅・故銅な ぞを原料として，電気銅950t/月の生産を行なつている。 製造設備の主な変遷はつぎのとおりである。

昭和 26 年 6 月：当社および神島化学工業株式会社, 藤 田興業株式会社，鐘淵紡績株式会社の 4 社で磁硫鉄鉣か ら硫酸製造を目的として西日本化学工業株式会社を設立 し，工場の建設に着手した。

昭和 28 年 9 月：同和鉱業株式会社は西日本化学工業株 式会社から経営を委託され，同和鉱業岡山製錬所とし て, 脱銅焼鉄鉱 $2,700 \mathrm{t} /$ 月，濃硫酸 $3,000 t /$ 月の規模で操 業を開始した。

昭和 31 年 7 月 : 焙焼炉 - 硫酸設備とも倍増工事完了。

昭和 35 年 10 月 : 銅製錬設備 $\left(11^{\prime} \phi\right.$ 流動炉 1 基, 1,200 $\mathrm{kW}$ 電気炉 1 基, 電解槽102槽を新設し, 電気銅 $400 \mathrm{t} /$ 月 の生産を開始した。

\footnotetext{
* 同和鈗業株式会社岡山製鍊所生産課長
}

昭和36年 9 月：硫酸製造設備のみを増設し, 硫酸生産 量を10,000t/月とした。

昭和37年 2 月 : 銅電解設備を増設し, 電気銅生産量を 95.0t/月とした。

昭和39年 1 月 : 硫化鉄鉣等の含銅量の増大に対処して 2 段焙焼法を完成し既設の焙焼炉附近の一部を改造した 昭和 40 年 3 月：銅製錬設備中，電気炉の操業を休止し た。

\section{2. 操 業の 概 況}

当所には上述のように，硫酸製造・脱銅燒鉄鉱製造部 門と電気銅製造部門の 2 つ部門があり，その操業系統 図を第 1 図に示す。

\section{$2 \cdot 1$ 硫酸・脱銅焼鉄鉱製造部門}

$2 \cdot 1 \cdot 1$ 原料鉱石 当製錬所の発足当時は，柵原磁 硫鉄鉱を主体として操業していたが，現在は硫化鉄鉱を 主体とし，それに柵原磁硫鉄鉣，金平磁硫鉄鉱，金平磁 鉄鉱などを調合して使用している。その鉣種別の成分は

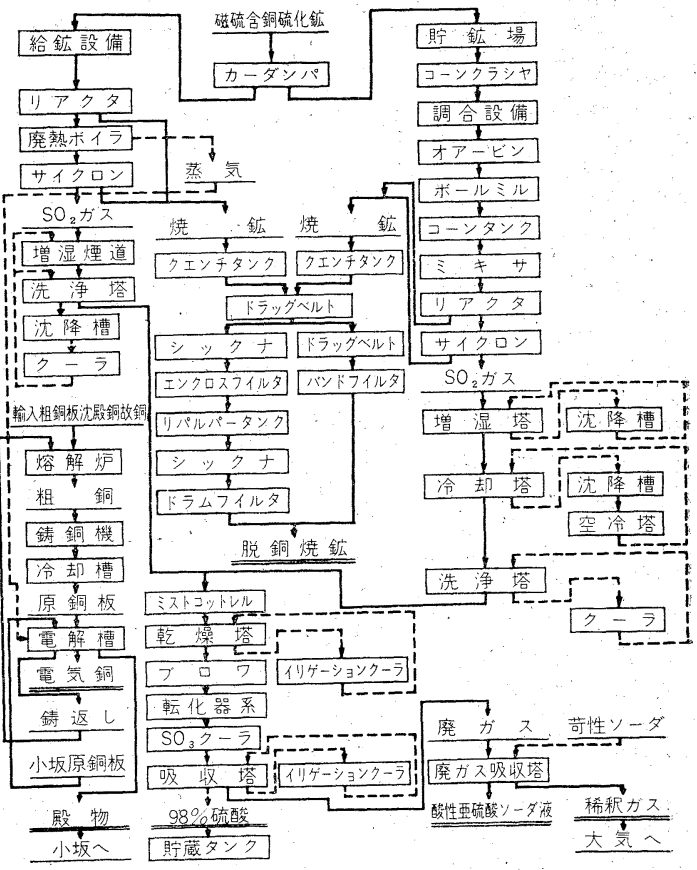

第1図 操業系 統図 
第1表のと㧍りである。

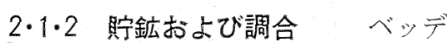
イング方式による鉱石の品位調合と貯 鈗を昭和 31 年 8 月以降採用している。 鉱石注貨車で入荷し，その貨車をカー ダンパを用いて傾転し荷卸しを行な う。鉱石はホッパからベルトコンベ ヤ，スタッカを経てベッディングヤー ドに送鉱される。ここに数種の鉱石は 品位により調合されながら均一な品位 の $1,000 \mathrm{t}$ の貯鉱の山を形成する。べ ッデングヤードからの払出しはリクレ 一マで貯鉱の一端からかき落し，1日 分をオアービンに揚鉱して，焙焼元鉱 とする。調合鉱石の基準品位は，入荷 鉱石の品位のかたよりによつて変動さ

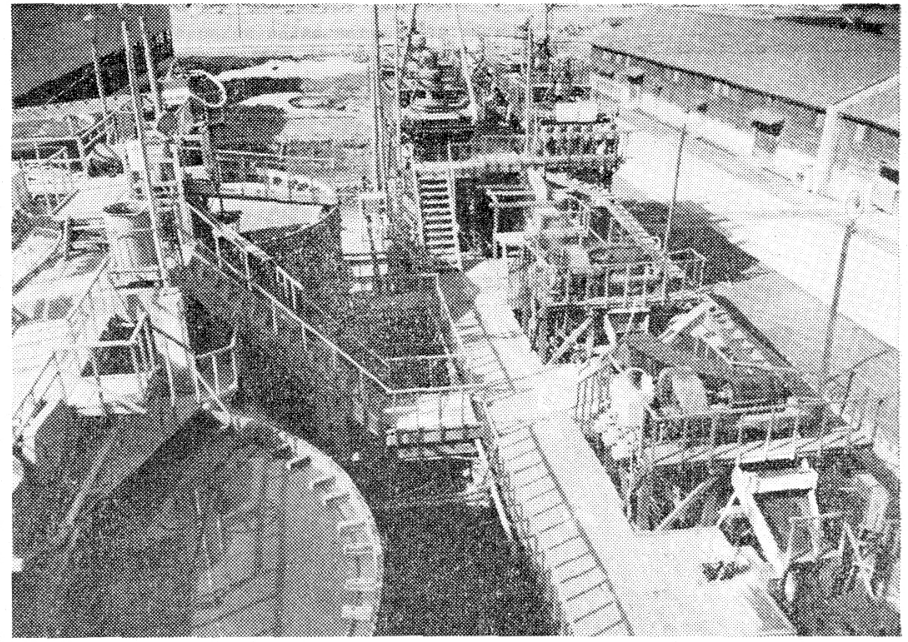

写真 1 燒鉣分級濃縮装置
せることも要る各，一応，鋦0.20\%，

鉄 $44 \%$ ，硫黄 41 ～ $42 \%$ である。

同一のベッデング内に预ける徐石品位のバラッキは, $\hat{\sigma}$ (標準偏差の推定值) で銅0.06\%，鉄0.41\%，硫黄0.42 \%である。

第1表 鉱石の成分表（\%)

\begin{tabular}{|c|c|c|c|c|c|c|c|c|}
\hline 成 分 & $\mathrm{Cu}$ & $\mathrm{Fe}$ & S & $\mathrm{Zn}$ & $\mathrm{Sc}$ & As & $\mathrm{SiO}_{2}$ & $\mathrm{CaO}$ \\
\hline 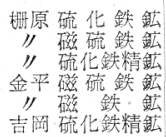 & $\begin{array}{l}0.26 \\
0.56 \\
0.29 \\
0.31 \\
0.06 \\
0.92\end{array}$ & $\begin{array}{l}43.84 \\
50.20 \\
42.04 \\
52.22 \\
59.89 \\
43.26\end{array}$ & $\begin{array}{l}47.39 \\
32.38 \\
46.30 \\
29.69 \\
19.14 \\
38.82\end{array}$ & $\begin{array}{l}0.24 \\
0.34 \\
0.16 \\
0.06 \\
0.09 \\
0.86\end{array}$ & $\begin{array}{l}0.012 \\
0.024 \\
0.007 \\
0.006 \\
0.001 \\
0.009\end{array}$ & $\begin{array}{l}0.035 \\
0.029 \\
0.058 \\
0.165 \\
0.155 \\
0.399\end{array}$ & $\begin{array}{l}5.84 \\
7.17 \\
4.53 \\
4.40 \\
5.52 \\
7.91\end{array}$ & $\begin{array}{l}0.17 \\
0.40 \\
0.52 \\
0.88 \\
2.90 \\
2.06\end{array}$ \\
\hline
\end{tabular}

設備の詳細は昭和33年，第 8 回全国鉱山製錬所現場担 当者会議で発表し，同しく議事録に収録されている。

2.1・3摩鉱、オォービンに揚鉱された鉱石は, その 下部からコンベヤによってメリック棌量器它経てマーシ 一型ボールミルで摩鉣される。さらにエーキンスタラッ シファイヤを用い全量を0.83 mm以下嚤鉱しアジテー タ付きのコーン型タンク内でパルプ比重2.4 2.5（約75 \%固型物）まで濃縮して焙燒元鉱とする。また硫化鉄精 鉱は別系統でホッパーから湳接リパルパータンクに送 り，同様に比重2.4 2.5のパルプを調整して，前記の元 鉱と混合して焙焼元鉱と寸る。焙焼炉への給鉱鉱石の粒 度分布老第 2 表汇示寸。

\section{第 2 表 給鉱鉱石の粒度分布 (\%)}

\begin{tabular}{|c|c|c|c|c|c|c|c|c|}
\hline 粒 & 度 $(\mu)$ & \begin{tabular}{l|l}
500 & 297
\end{tabular} & 250 & 177 & 149105 & 74 & 62 & $44-44$ \\
\hline \multicolumn{2}{|c|}{$\begin{array}{l}\text { 森ールル出口 } \\
\text { 硫化鉄 精触 }\end{array}$} & $\begin{array}{ll}3.6 & 9.4 \\
- & -\end{array}$ & 6.3 & $\begin{array}{r}7.5 \\
-\end{array}$ & 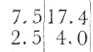 & $\begin{array}{r}18.2 \\
3.0\end{array}$ & $\begin{array}{l}4.9 \\
3.6\end{array}$ & $\begin{array}{l}3.921 .3 \\
6.780 .2\end{array}$ \\
\hline
\end{tabular}

$2 \cdot 1 \cdot 4$ 焙焼焙焼の方式注岡山製鍊所独自の 2 段 焙焼法を採用している。これは硫酸工場の生産性の向上
を計りながら同時汇燒鉱からの銅の溶解抽出も容易化す る目的で，鉱石を 1 号炉で高 $\mathrm{SO}_{2}$ ガス濃度の雲囲気で酸 化焙焼し，关の焼鉱を高温のまま 2 号炉移動させて， ここで若干の鉣石とともに低 $\mathrm{SO}_{2}$ 濃度の雾囲気で焙燒を 行ない，この硫酸化焙焼雲国気中で鉱石の焙焼と焼鉱の 再焙焼を同時に行なら方式である。

鉣石の焙焼炉への給鉱注前述の75\%固型物のパルプを それぞれの炉の3 4個所のフィードノズルから行なつて いる。給鉱方式は O.D.S ポンプによる間歇給鉱と炉頂 部の分散箱による連続給鉱定併用しているが，いずれも 運転室内にて給鉱量の加減調整が可能である。

焙焼温度は 1 号炉 $670^{\circ} \mathrm{C} ， 2$ 号炬 $630^{\circ} \mathrm{C}$-゙，硫酸工場の 廃薄硫酸を直接炉内に注入して調整している。流動層高 さは1,2号炉とも従来 $1,500 \mathrm{~mm}$ であつたもの在焙焼処理 鉱量の増加をはかるため $1,200 \mathrm{~mm}$ に改造した。

焙焼のガス濃度は泠却塔出口部の $\mathrm{SO}_{2}$ メーターで 1 号 炉は14 14.5\%の酸化焙燒，2 号炉は元鉱の含銅品位の 高低によつて7.0 10\% と, そのつど焼鉱の銅抽出に適合 した条件で硫酸化焙焼孛行なつている。この2 段焙焼で は燒鉱への脱銅性の付与は 2 号炉だけで行ならもので, 2 号炉の焙焼条件が最も重要な鍵となつている。

一例を㐫げると元鉣の含銅品位 $0.6 \%$ 以下で㐫れば， 発生 $\mathrm{SO}_{2}$ 濃度 $7.5 \%$ ，含銅品位0.4\%ならば9.0\%になる ように給釷量を操作する。したがつて元鉣の含銅品位の

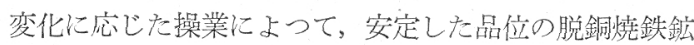
を製造することになり，逆に硫酸生産量の増加をはかる た好，元鉱の配合品位を所定の值に固定することも容 易になつた。

1 号炉で焙燒された焼鉱は，炉才ーバーフローおよび サイクロンの各フローシールを経て，エァースライドで 
2 号炉に連続的に移送され再焙焼される。各エァースラ イド出口にある温度計で内部の焼鉣温度を測定し，焼鉱 の停帯や移動の状況を監視することも可能である。2 号 炉で流酸化焙焼雾囲気中で, 焼鉱を再焙焼し, 焼鉱は 2 号炉のオーバーフローとサイクロンを経てクエンチタ ンクに入る。クェンチタンクの中で $1.5 \sim 2.5 \%$ 硫酸に よりリパルプされて約 $200 \mathrm{~m}$ 離れた脱銅工場までパルプ 流送される。

焼鉱中の銅分の溶解率は焙焼条件，元鉱の含銅品位に よつて多少の差があるが，1号炉の炉焼釷15２5\%，少 イクロン焼鉱 40 50\%で，再焙燒後の 2 号炉燒鉣ではと もに75 85\%となり，銅の溶解性は大きく増加されてい る。

焙燒についての詳細は，硫酸誌第19巻ならびに第12回 全国鉱山製錬所現場担当者会議工務部会講演集に記載さ れている。

なお， 2 段焙焼の系統略図を第 2 図で示す。

$2 \cdot 1.5$ 脱銅・脱硫焙焼工場から脱銅工場にパル プ流送された焼鉱は，流送途中で可溶性の銅分は大部分 が溶解抽出される。焼鉱はドラッグベルト分級機で粗粒 鉱と微粒鉱とに分級され粗粒鉱はドラッグベルトにより 4 回の洗浄を経て, ルルギ式バンドフィルタで脱水後, 続けて清水洗浄を同時に行なつて，脱銅・脱硫処理の製 品燒鉱となる。一方, 微粒鉱を含むパルプは, シックナ 4 基で洗浄後, 一旦フィルタで脱水し，続いて清水中に 入れてリパルプして, さらにシックナ 2 基で洗浄して再 びフィルタで脱水して製品の脱銅燒鉣となる。この最後 の水洗工程は脱銅処理後の焼鉱に付着水として含まれる 銅分と硫酸塩類を除去するためのものである。

脱銅工程における 1 号シックナのオーバーフローは焙 焼炉のクエンチタンクに送液されて, 焼鉱の銅分溶解用 に, 2 号シックナのものは銅液として, 収銅槽に送られ る。収銅槽は送風式収銅槽で鉄原を投入して銅液中の銅 を沈殿銅として回収する。この尾液は脱銅工場の焼鉣洗 浄用ならびに硫酸工場のガス精製部門の補給液として用 レている。

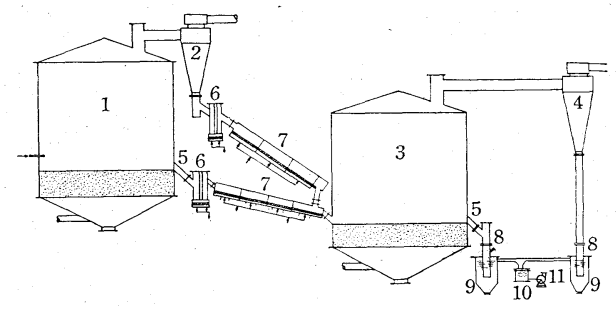

1. No.1流動炉 2. 同サイクロン 3. No. 2 流動炉 4. 同 サイクロン 5. 炉䢿鉱オーベーフロー 6.フローシール 7. エヤースライドとい 8. シールパイプ 9. クエンチングタン

ク 10. コレクションタンク 11. スラリポンプ

第 2 図 焙焼系統略図

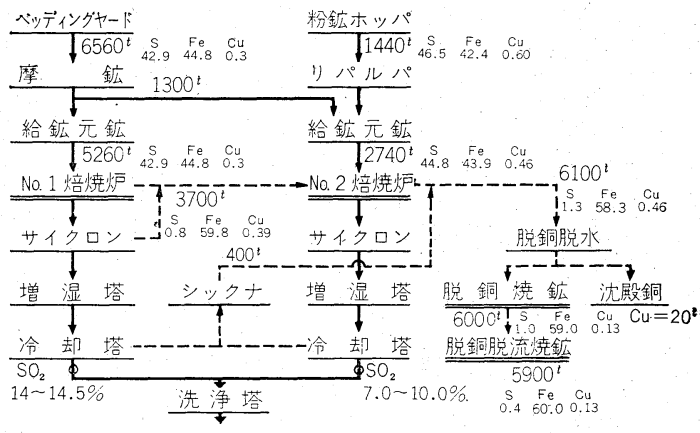

第 3 図 2 段焙焼操業例 (月間物量収支)

月間の操業成績を物質収支としてまとめた一例を第 3 図に示す。

$2 \cdot 1 \cdot 6$ 硫酸なよび廃ガス処理㥉焼炉からの生成 覀硫酸ガス濃度注乾燥状態換算で10.0 11.0\%，湿分は $25 \sim 30 \%$ 程度である。流動焙燒炉の特性からガス中には ダストの飛散が多く, サイクロン以降のガス中にも, な お30 $/ \mathrm{Nm}^{3}$ のダストを含んでいる。この量は全生成焼鉱 の3 6\%に相当し硫酸工場の湿式ガス洗浄装置 (冷却・ 洗浄塔など）でフライングダストとして捕集される。こ の捕集ダス卜は上記焼鉱と同様に脱銅工場に送り製品脱 銅焼鉱となる。

冷却洗浄されたガスは，さらに6.5 7.5\%まで稀釈さ れて転化器を経て, 濃硫酸となる。

一般の硫酸工場の排ガスは，そのまま大気中に放出さ れているが，当製錬所では，昭和 32 年に排ガス中に含ま れている $\mathrm{SO}_{2}$ ガスの回收と公㲅防止の目的で，排ガスの アルカリによる中和吸収設備の建設を完了し, 直ちに操: 業を開始した。以来数回の改造と増強を実施して, 現在 は向流 2 塔式のガス吸収法を採用している。なお塔は石 川島播磨重工製のエアロテックーターブレントーコンタ クトーアブソーバー（T.C.A)を採用し，良好なガス吸 収の成績を得て公害の防止に役立つている。

\section{$2 \cdot 2$ 電気銅製造部門}

緒言にて述べたように，銅抽出液からの電気銅採取を 主体にあわせて輸入銅精鉱を処理するための設備として 焙焼熔鍊電解の一連の製鍊設備を建設し，昭和 34 年末ま ず電解工場が完成し採取電解を開始した。ついで電気炉, 焙焼炉が完成し 35 年10月より 400t/月の電気銅生産を行 なつていたが，硫化鉄鉱中の銅分の低下にともない採取 電気銅量も減じてきたので, 再度これを沈殿銅採取方式 に切替えるとともに採取電解設備を精製電解設備に転用 し，あわせて沈殿銅，スクラップを処理するため熔解炉 を建設した。

しかし，昭和 40 年 3 月に臨海大規模製鍊所である小名 浜製錬に参加するために，電気炉製錬の操業は中止し， 
かわりに輸入粗銅，スクラップ等を原料として現在，月 産 $950 \mathrm{t}$ の電気銅を生産している。

なお，電気炉製錬に関する操業概況，成績，操業上の 問題点等については, 昭和 38 年 5 月の第13回全国鉱山製 鍊所現場担当者会議にて報告し，同製錬講演集に掲載さ れているので，ここでは省略することにする。

$2 \cdot 2 \cdot 1$ 愹解炬操業 愹解炉注能力 $35 \mathrm{t} /$ 日のロータ リーファーネスで1日1サイクル（原料装入〜熔解〜カ ラミ取り〜風掛〜ボーリング〜鋳銅）の操業であり，熔 解は重油バーナによつて行なう。原料が大部分粗銅なの で煙灰の発生はほとんぞないが，廃ガスは煙室，増湿 塔, 洗浄塔をとおして大気中に放出している。カラミ取 りは装入口より人手によつてかき出し, 風掛は装入口に 設けられた小孔より1.5” のパイプを捙入して行ない,ポ ーリングは松丸太をバーナロより投入している。鋳銅は 直進式の鋳銅機で 1 回13枚で所要時間は 7 8min/回程 度である。アノード重量は $135 \mathrm{~kg} /$ 枚で, 銅リボン吊手 である。

第 3 表に操業成績の概略を, 第 4 表に産出精製アノー ドの品位を示す。

\section{第 3 表}

\begin{tabular}{|c|c|c|c|c|c|c|}
\hline & 操 & 業 & [ & 数 & & 1 回/月 \\
\hline $\begin{array}{l}\text { 撚 } \\
\text { 䢬 } \\
1\end{array}$ & 回 & $\begin{array}{l}\text { 元 } \\
\text { の 操 }\end{array}$ & $\begin{array}{l}\text { 料, } \\
\text { 剂 } \\
\text { 策 }\end{array}$ & 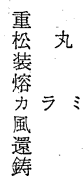 & $\begin{array}{l}\text { 油 } \\
\text { 太 } \\
\text { 入 } \\
\text { 解 } \\
\text { 扳 } \\
\text { 掛 } \\
\text { 元 } \\
\text { 銅 }\end{array}$ & \begin{tabular}{cc}
\multicolumn{3}{c}{$120 \mathrm{l} / \mathrm{t}$-anode } \\
25 & $\mathrm{\prime \prime}$ \\
1.0 & $\mathrm{~h}$ \\
18.4 & $\mathrm{\prime \prime}$ \\
0.5 & $\mathrm{\prime \prime}$ \\
0.7 & $\mathrm{\prime \prime}$ \\
0.7 & $\mathrm{\prime \prime}$ \\
2.7 & $\mathrm{\prime \prime}$
\end{tabular} \\
\hline
\end{tabular}

\section{第 4 表}

\begin{tabular}{l|c|c|c|c|c|c}
\hline \hline 名称 & $\mathrm{Au}$ & $\mathrm{Ag}$ & $\mathrm{Cu}$ & $\mathrm{Pb}$ & $\mathrm{Zn}$ & $\mathrm{Fe}$ \\
\hline 精製アノード & 5.7 & 295 & 98.83 & 0.10 & 0.006 & 0.005 \\
\hline \hline 名称 & $\mathrm{S}$ & $\mathrm{As}$ & $\mathrm{Sb}$ & $\mathrm{Bi}$ & $\mathrm{Ni}$ & $\mathrm{Sn}$ \\
\hline 精成アノード & 0.005 & 0.010 & 0.010 & 0.008 & 0.086 & 0.001 \\
\hline
\end{tabular}

$\mathrm{Au}, \mathrm{Ag}$ は g/t, その他は \%

\section{$2 \cdot 2 \cdot 2$ 電解操業 電解槽数:は 170 槽でウォルカ式 2} 段カスケード方式である。直流電源はシリコン整流器で $7,000 \mathrm{~A}$ 電流容量である。浄液設備はもたず, $\mathrm{Cu}$ 量 15 $\mathrm{g} / \mathrm{l}$ まで脱銅電解を行なつたあとは硫酸部門の焙焼焼鉱 の浸出にまわしている。

またスライムは当所にはその処理設備がないので, 全 量小坂鈗業所送つている。

アノードスクラップは熔解炉に繰返して, 輸入粗銅,
·第 5 表

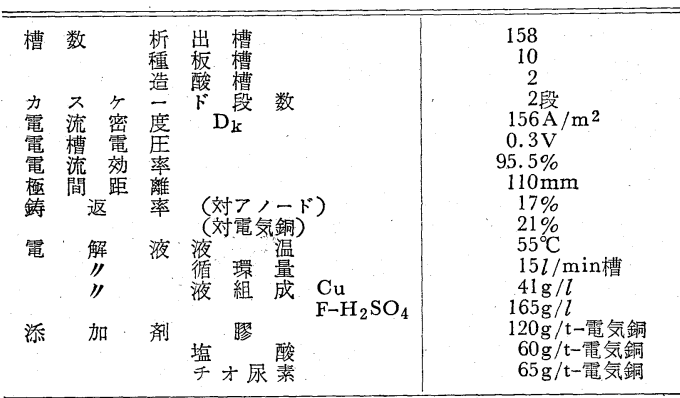

第 6 表

\begin{tabular}{|c|c|c|c|c|c|c|}
\hline 名称 成分 & $\mathrm{Au}$ & $\mathrm{Ag}$ & $\mathrm{Cu}$ & $\mathrm{Pb}$ & $\mathrm{Zn}$ & $\mathrm{Fe}$ \\
\hline 生産電気 銅 & $\operatorname{tr}$ & 6 & 99.99 & 0.0005 & - & 0.0005 \\
\hline $\begin{array}{l}\text { アノードスライ } \\
\text { ム }\end{array}$ & 451 & 24,000 & 21.50 & 20.46 & 4.06 & 0.25 \\
\hline 名称 成分 & S & As & $\mathrm{Sb}$ & $\mathrm{Bi}$ & $\mathrm{Ni}$ & Sn \\
\hline 生産電 気 銅 & 0.0018 & 0.0001 & 0.0001 & 0.0001 & - & - \\
\hline アノードスライ & 7.33 & 0.14 & 1.39 & 0.052 & 1.30 & 4.86 \\
\hline
\end{tabular}

スクラップ等と同時に熔解している。

操業成績の概略を第 5 表, 電気銅掠よびアノードスラ イムの品位を第 6 表に示す。

\section{3. 結言}

以上，岡山製錬所における最近の硫化鉄鉣の脱銅操業 と銅の製鍊についての設備・操業の概況を述べたが，い ずれも生産規模が小規模設備であるために, 設備の能率, 合理化の面で遅れていて，今後は設備の大型化による生 産性の向上をはかる必要がある。

硫酸焼鉄鉱の部門については，単なる大型化によるコ ストの低減をはかるのみでなく, 現在の焼結原料である 脱銅焼鉱をさらに一歩進めて，塩化揮発や塩化焙焼など の方法を採用して，焼鉱中の有価金属の回収，製鉄用不 純分の完全除去を行なつて，より高品位な製鉄原料とす ることもあわせて検討して行きたい。

一方，銅製鍊部門についても現在の $950 t /$ 月規模では 設備の機械化も採用し難いため, 設備の大型化, 運搬の 合理化，高電流密度操業を採用したい。

また柵原硫化鉱の高度活用として，従来の製鉄用原料 にとどまらず, 硫化鉄鉱・焼鉱の高純度化を進め, 将来, 粉末治金用鉄原料ならびに磁性体用原料など新製品開発 の分野への研究も進めたいと考えている。 